\title{
Soft Tissue Tumors in Palaeopathology: A Review
}

\author{
Gino Fornaciari Valentina Giuffra \\ Division of Paleopathology, History of Medicine and Bioethics, Department of Oncology, Transplants and \\ Advanced Technologies in Medicine, University of Pisa, Pisa, Italy
}

\section{Key Words}

Cancer $\cdot$ Mummies $\cdot$ Palaeopathology $\cdot$ Soft tissue tumors

\begin{abstract}
Objective: To perform a review of soft tissue tumors in palaeopathology. Methods: Examination of palaeopathological literature. Results: Up to now, observations of neoplastic soft tissue lesions in mummified remains are limited to 15 cases, and only 4 of them present malignancies; 14 cases of calcified benign tumors, including 13 neoplasms of the female reproductive system and 1 teratoma, are also documented. Conclusions: The main reasons for the rarity of soft tissue tumors in palaeopathology, especially of malignancies, are apparently the short life span of past populations, the scarcity of mummified remains available in comparison with skeletal remains, and technical difficulties in the detection of neoplastic lesions in mummified tissues.
\end{abstract}

Copyright $\odot 2012$ S. Karger AG, Basel

\section{Introduction}

The relative abundance of neoplastic lesions documented so far in the palaeopathological literature, which are distributed over a long time span and in different geographic areas $[1,2]$, demonstrates that a number of tumors affected past populations.
Nevertheless, although cancer nowadays represents the first cause of death in people $<85$ years [3], its incidence in the past was certainly less high for two main reasons. Firstly, the average age at death in the pre-modern era was considerably lower than in the present; this fact implied that an individual generally died before reaching the 4 th or 5 th decade of life, when the probabilities of developing a cancer are highest. Secondly, several environmental factors, which nowadays play an important role in neoplastic transformation, such as pollution, cigarette smoke and some drugs, did not exist in the past. However, past populations were equally subjected to some carcinogenic factors, such as chemical substances present in nature, ultraviolet radiation and oncogenic viruses, for example [4].

Besides these reasons, it is also necessary to consider other aspects in order to explain the lower frequency of tumors in the epidemiology of past populations. For example, the attention of researchers has been focused only recently on the study of neoplastic pathologies in ancient human remains; furthermore, solid palaeopathological training is necessary to recognize the signs of neoplastic lesions in ancient bodies; it is therefore probable that several cases had not been correctly identified and recorded. In addition, the study of ancient tumors depends on the state of preservation of the findings; natural factors and anthropogenic interventions can damage ancient human remains so that identification of pathological conditions becomes difficult. Finally, in most cases, ancient human

\section{KARGER}

Fax +4161306 1234

E-Mail karger@karger.ch

www.karger.com
(C) 2012 S. Karger AG, Basel

$1015-2008 / 12 / 0795-0257 \$ 38.00 / 0$

Accessible online at:

www.karger.com/pat
Prof. Gino Fornaciari

Division of Paleopathology, History of Medicine and Bioethics

Department of Oncology, Transplants and Advanced Technologies in Medicine University of Pisa, IT-56126 Pisa (Italy)

Tel. +3905099 2894, E-Mail gino.fornaciari@med.unipi.it 
Fig. 1. Histology of rectal carcinoma in an Egyptian mummy of Roman age. a Transition from normal mucosa on the left to villous adenoma. b Muscularis invasion indicates malignant transformation (by courtesy of Prof. Michael R. Zimmerman) [6].
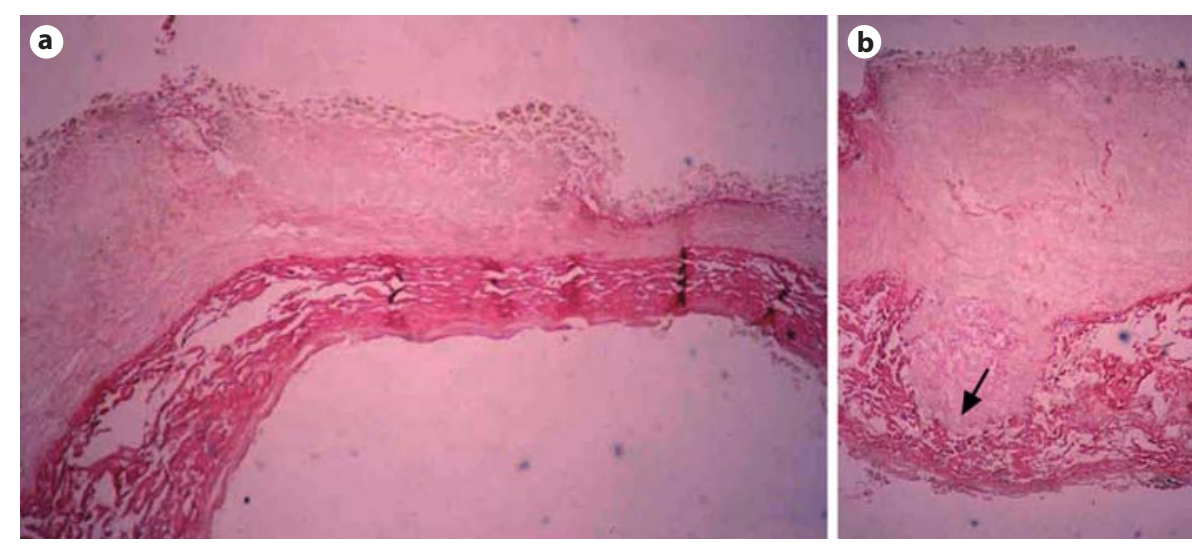

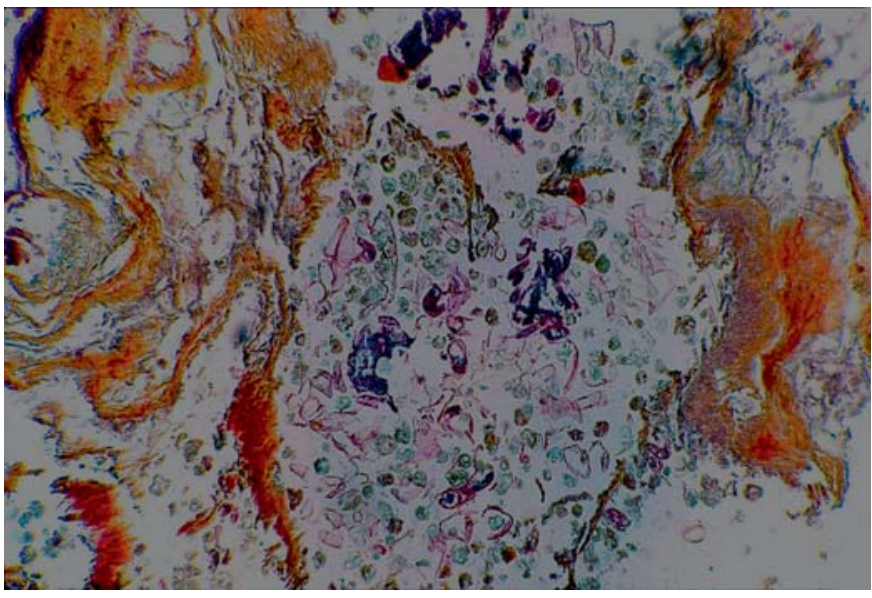

Fig. 2. Histological section of rhabdomyosarcoma in a Chilean mummy (by courtesy of Prof. Enrique Gerstzen) [7].

remains reach us as skeletons without preserved soft tissues; the largest opportunities to observe pathological lesions are therefore confined to skeletal remains, whereas the detection of tumors in mummies has to be considered a lucky chance.

As a matter of fact, dozens of cases of tumors affecting the skeletal apparatus are described in palaeopathological literature, but only a few records are documented in soft tissues.

\section{Evidence of Neoplasms in Mummies}

\section{Malignant Tumors}

Egyptian mummies represent an exceptional archive of biological data, from which precious information about the health conditions of ancient Egyptians can be obtained. In a male adult mummy, coming from the Dakhleh Oasis (Egypt) and dated back to the Roman period, an abnormal tissue mass was found in the rectum and examined histologically. Analysis demonstrated degenerated epithelial cells but with non-invasive, adenomatous structure (fig. 1a); other sections showed clear invasion and infiltration into the submucosa of an atypical glandular component (fig. 1b, arrow). Rectal carcinoma was the diagnosis suggested $[5,6]$.

Another case of malignant tumor was detected in the soft tissues of South American mummies. A male child (12-18 months of age) from northern Chile belonging to a culture dating from 300 to $600 \mathrm{AD}$ presented a lesion $5.5 \times 5 \times 2 \mathrm{~cm}$, which was localized to the right cheek, below the eye, which resulted to be forcedly closed. Histological sections showed pleomorphic, disintegrated cells surrounded by fibrous stroma (fig. 2). These features are typical of rhabdomyosarcoma, a malignant neoplasm affecting subadults [7].

The Italian territory has provided some significant cases of ancient soft tissue cancer; although the climate is not particularly favorable for the preservation of bodies, specific microclimatic conditions present in some environments, mainly churches, allowed a natural process of mummification, with an excellent state of conservation of soft tissues.

The dry microclimatic conditions of the Basilica of S. Domenico Maggiore in Naples (southern Italy), where several mummies of Renaissance Aragonese princes and nobleman are preserved, favored an excellent state of preservation of soft tissues and internal organs; the substances used for embalming, including aqua vitae to wash the corpses and resins to be poured in the body cavities, protected the integrity of the tissues, making it possible to perform histological examination. 

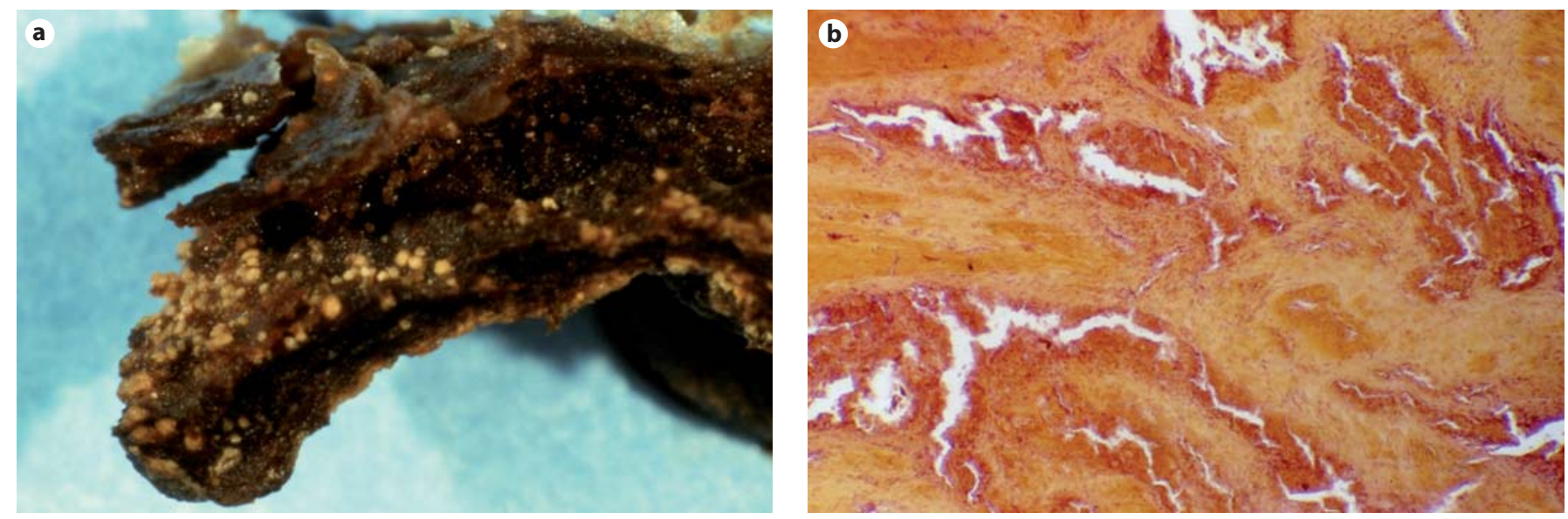

Fig. 3. Tumor of King Ferrante I of Aragon with small roundish gray-white areas (a) and HE staining of the colorectal carcinoma $(\times 200)[11]$.

In the mummy of Ferrante I of Aragon (1431-1494), King of Naples, a hollow fibrous structure was macroscopically observed in the small pelvis (fig. 3a). Histological examination showed neoplastic cells, disposed in cords, solid nests and glands, disseminated in a fibrous tissue containing striated muscular fibers (fig. 3b); mucus was scarce and limited to pseudoglandular formations. These features suggested an adenocarcinoma, probably originating from the colon or prostate. The excellent preservation of the neoplastic cells encouraged molecular analyses designed to investigate the primary origin of the tumor. DNA analysis revealed the presence of $\mathrm{K}$-ras codon 12 mutation, demonstrating that the tumor was a mucinous colorectal adenocarcinoma. Mutation of the K-ras gene is associated with exposure to chemical carcinogens, probably present in the diet; a palaeonutritional study with carbon- and nitrogen-stable isotopes $\left({ }^{13} \mathrm{C}\right.$ and $\left.{ }^{15} \mathrm{~N}\right)$ indicated a large consumption of meat by King Ferrante [8-11].

The natural mummy of Ferdinando Orsini, Duke of Gravina in Apulia (southern Italy), revealed at macroscopic and X-ray examination a large osteolytic lesion of the skull, extending from the interior angle of the right orbit through the nose root and the glabella, up to the frontal sinus, also affecting the ethmoid bone (fig. 4a). The lesion showed irregular margins with no signs of reparative, sclerotic reaction. Histological examination showed necrotic cell groups of solid epithelial-like aspect, with large osteolytic lacunae (fig. 4b, arrow). The destructive features of the lesion and absence of reaction of the surrounding bone tissue strongly suggested a primitive malignant neoplasia of the face. The application of the monoclonal antiserum against the pancytokeratin KL1 (Sorin) yielded at indirect immuofluorescence an intense positivity of the cellular membrane of the neoplastic cells, confirming the epithelial nature of the tumor; a diagnosis of periorbital skin carcinoma was suggested, which was most likely consisting of basal cells. Malignancy caused the destruction of the ocular right eyeball, with consequent blindness, probably also of the left eye, due to direct invasion; the involvement of the nose and orbits disfigured the face of the Duke, making it necessary to cover it with a veil at the moment of burial [12].

Another report concerns the possible diagnosis of melanoma in 9 pre-Columbian mummies from Peru dating back to $400 \mathrm{BC}$. Hair follicles and rounded melanotic masses were observed on the skin, whereas osteolytic lesions, interpreted as melanomas, affected the skull and bones of extremities. The diagnosis was based uniquely on macroscopic examination and, therefore, in the absence of histologic confirmation [13], these cases were not included in the review.

\section{Benign Tumors}

The benign tumors of soft tissues are better documented in the palaeopathological literature.

In 1821, Granville [14] performed an autopsy on an Egyptian mummy from Gurna and observed anomalies affecting the genital apparatus. The body, belonging to a 50/55-year-old woman, showed an abnormal enlargement of the uterus, with the remains of a sac connected to the left ovary; on the right side, the ovary and the broad ligament were enveloped in a mass of pathological struc- 
Fig. 4. a Head of Ferdinando Orsini with the lytic lesion affecting the interior angle of the right orbit and the nose root. $\mathbf{b}$ Histology of the diffuse carcinoma infiltrating facial bone tissue $(\times 200)[12]$.
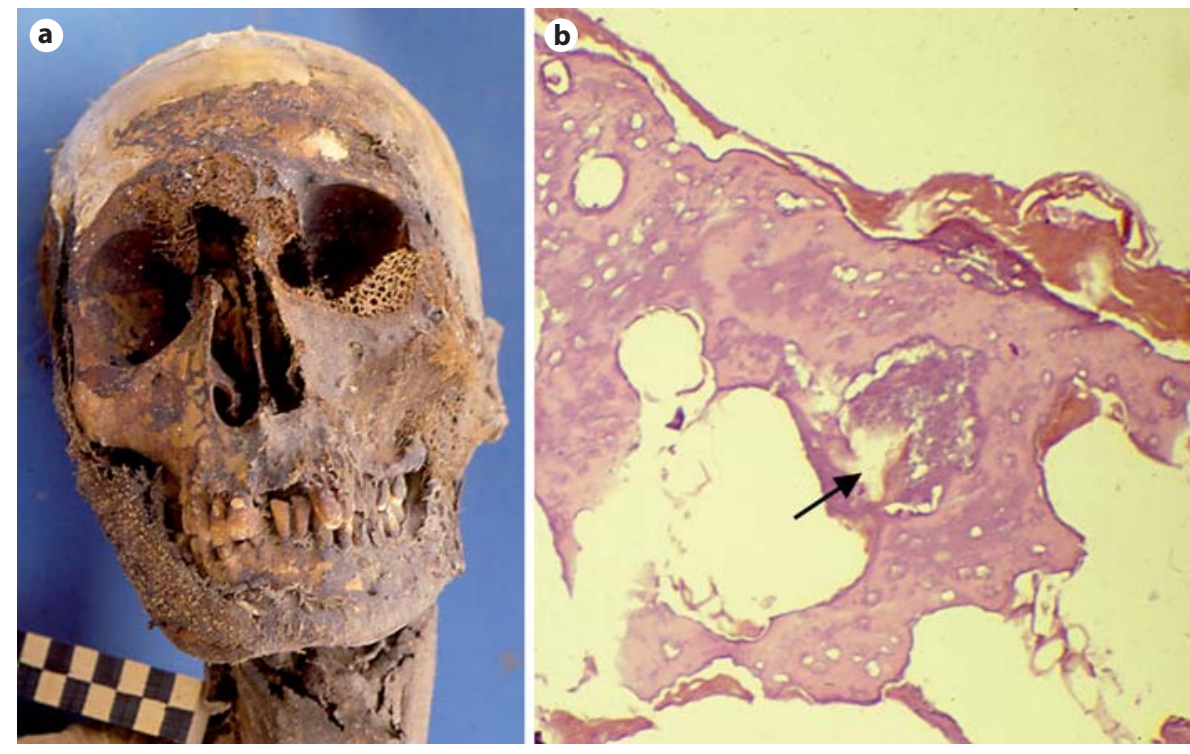

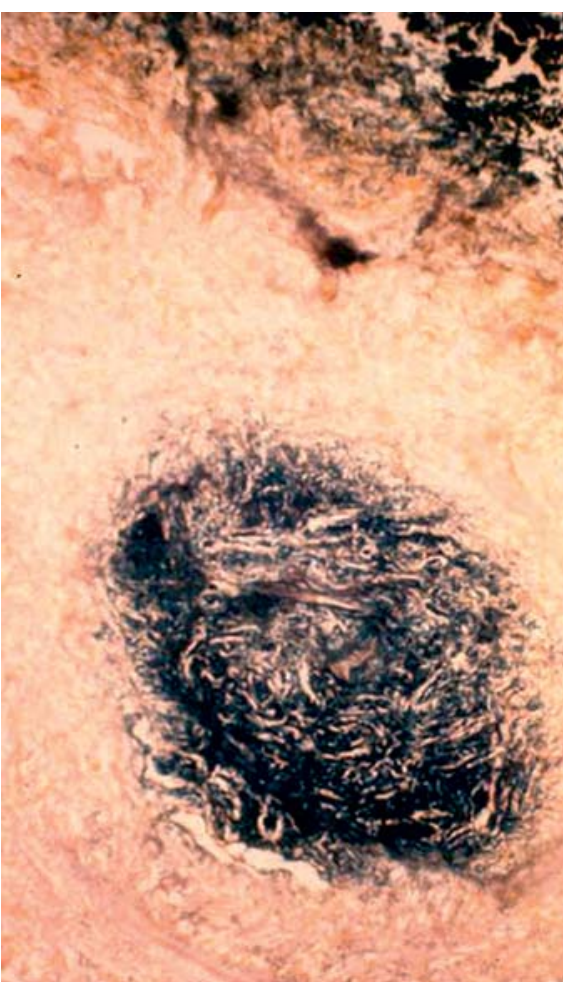

Fig. 5. Histology of fibrous histiocytoma of the skin in an Egyptian mummy ( $\times 40$; by courtesy of Prof. Michael R. Zimmerman) [16]. ture. Granville [14] states: 'the disease which appears to have destroyed her was ovarian dropsy attended with structural derangement of the uterine system generally'. The drawing of plate XXII/1 reveals a globular uterus standing above a tangle of structure from which a normal right tube and a three strap-like left tube start. The description of Granville led to hypothesize that the woman was affected by a bilateral cystadenoma or cystadenocarcinoma of the ovary [15].

Dermal neoplasia was histologically observed on the skin of a mummified left heel from a tomb of Upper Egypt (1290 BC to 200 AD). The lesion showed a small amount of fine fibrous tissue, with positive iron staining at histochemistry and necrosis of the overlying epidermis (fig. 5). The dermal location, the features of the lesion and the presence of iron stain suggested a diagnosis of histiocytoma [16].

Another dermatologic lesion was reported in a female Egyptian mummy, probably of the late dynastic age, with a small 'filiform' neoformation of the hand; histological analyses evidenced a squamous papilloma [17].

The Egyptian mummy known as PUM III, belonging to a 35 -year-old female and dated approximately to 835 $\mathrm{BC}$, revealed a little nodule of $1 \mathrm{~cm}$ in diameter in the lateral region of the left breast. At histology, the nodule proved not to be composed of fat tissue, as the normal breast, but of connective tissue, with elements recognizable as epithelial cells. The histological features, localization, dimensions and age of the woman suggested a diagnosis of fibroadenoma [18]. 
Fig. 6. Histology of urinary bladder papilloma (grade 1 carcinoma) in an Egyptian mummy (by courtesy of Prof. Michael R. Zimmerman) [6].

Fig. 7. Section of verruca vulgaris in an Egyptian mummy (by courtesy of Prof. Ezio Fulcheri) [19].
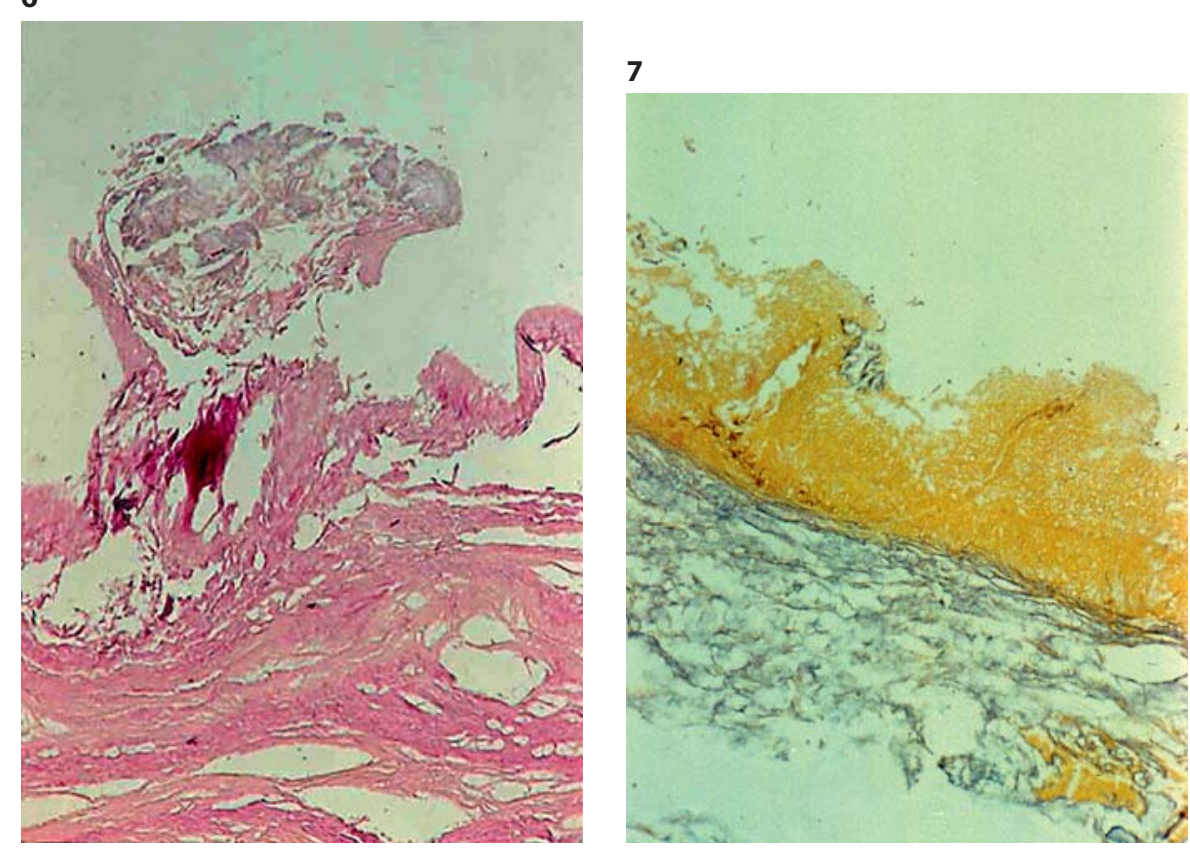

Macroscopic examination of the bladder in an adult male mummy from the Dakhleh Oasis (Egypt), dated back to the Roman period, evidenced a small papillary excrescence, with small clusters of cells surrounded by reticulin, interpreted as an epithelial tumor, in particular a papilloma (or low-grade carcinoma) of the bladder (fig. 6) [6].

On the neck of an Egyptian mummy from the Marro Collection, Turin, Italy (No. 61), a protruding lesion 0.7 $\mathrm{cm}$ in diameter was observed. This was a raised, roundish mass, brown in color, interpreted as a verruca vulgaris. Histology showed thickened epidermis with hyperkeratosis, parakeratosis, mild acanthosis and some vascular spaces (fig. 7), and slight positivity to anti-keratin antibodies [19].

The poorly preserved body of an adolescent male aged 14 years from Northern Chile (110 to 1200 AD) showed a subcutaneous mass on the right thorax, approximately $6 \mathrm{~cm}$ under the axilla. Histology revealed a conglomeration of fat cells mixed with fibrous septa (fig. 8). The microscopic features are those of a benign lipoma [7].

Eight ulcerated lesions affected the legs of a frozen Inca mummy found at high altitude in the Andes, on Cerro El Plomo, Chile; this 9-year-old boy, also known as 'Prince of El Plomo', was the victim of a human sacrifice. The lesions were $0.5-1 \mathrm{~cm}$ in diameter and had definite borders; microscopic examination showed the presence of dilated vascular channels in the superficial der-

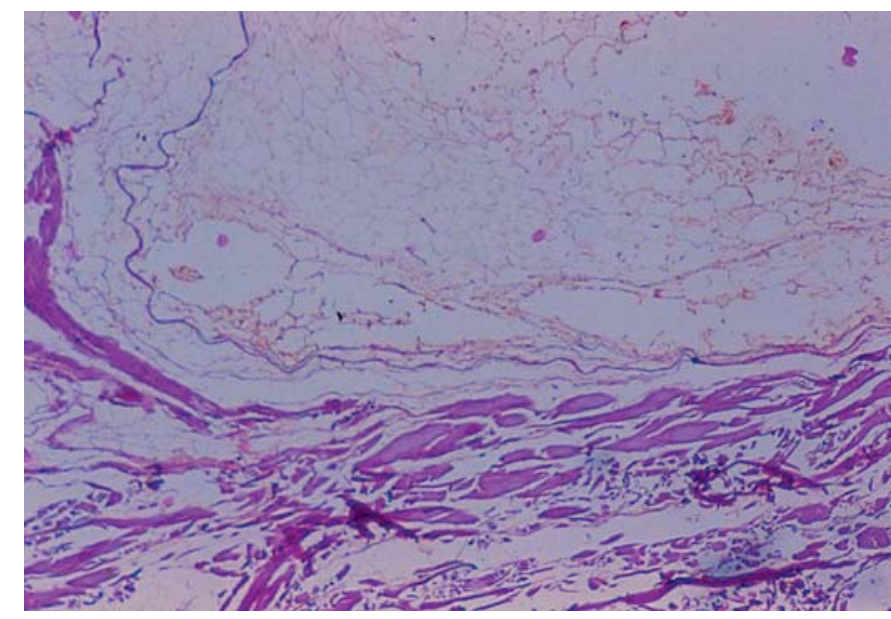

Fig. 8. Histological section of lipoma in a Chilean mummy (by courtesy of Prof. Enrique Gerstzen) [7].

mis and, larger, in the subcutaneous fat. The epidermis presented a papillary structure and was covered with fibrinous exudate. The histological picture was consistent with an angiokeratoma circumscriptum. In the same mummy, two small lesions were observed at the base of the thumb and index fingers of the left hand. These two rounded neoformations of $2 \mathrm{~mm}$, examined with transmission electron microscopy, allowed a diagnosis of ver- 
Fig. 9. a Skin neoformation in the paravulvar region of Maria of Aragon. b Histological section of condyloma acuminatum [23].
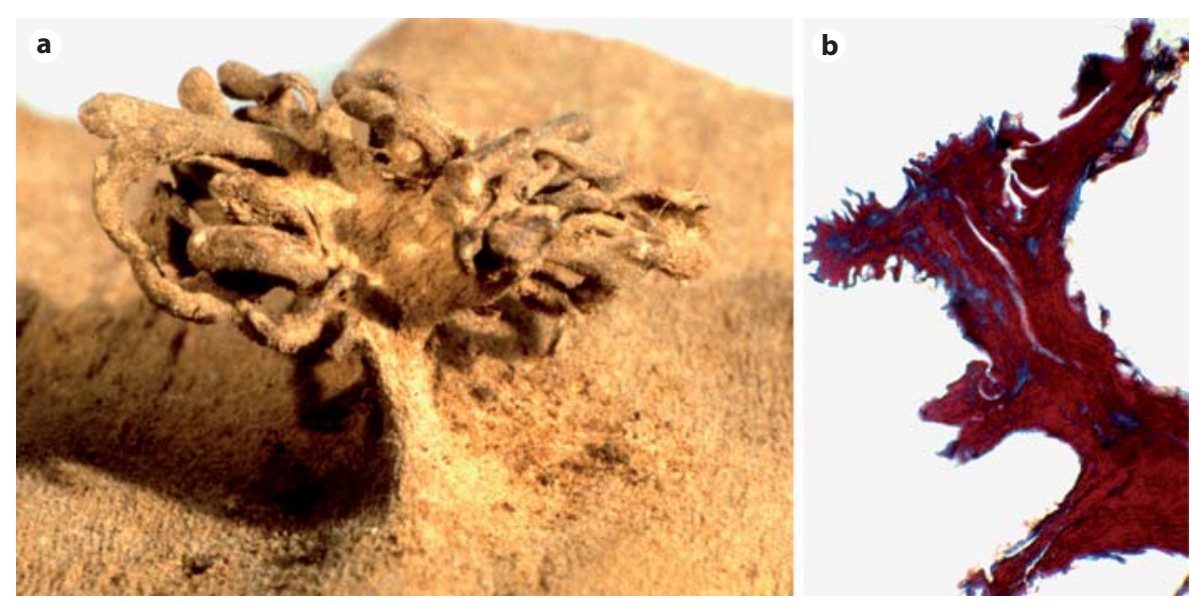

ruca vulgaris, with presence of viral-like, round structures, identified as possible human papilloma virus (HPV) [20, 21].

Among the natural mummies found in the Convent of S. Georg of the Observants in Goriano Valli (L'Aquila, central Italy), dated back to the second half of the 19th century, the body of a woman aged 43-50 years revealed the presence of a neoformation in the abdominal cavity. CT examination showed a cribrous mass in the right iliac fossa and pelvis, with abundant fibrous component and absence of elements referable to a normal organ. This neoformation seems to be referred to an ovarian neoplasia, probably a cystadenoma or a teratoma, although it was impossible to establish the grade of malignancy; the perivesical calcific nodules could represent the inflammatory process of the regional lymph nodes [22].

The artificial mummy of Maria from Aragon (15031548), Marquise of Vasto, in the Basilica of S. Domenico in Naples, showed the presence of a large pedunculated branching skin neoformation in the right paravulvar region (fig. 9a). Hematoxylin-eosin histology, and Masson's trichrome staining, allowed to observe an exophytic papillary skin lesion, with thickened epidermis and less dense internal tissue with dilated vessels, suggesting the diagnosis of condyloma acuminatum (fig. 9b), a squamous lesion of the external genitalia and perianal areas induced by HPV. Amplification of DNA allowed to detect the presence of HPV 18, a virus with high oncogenic potential, in particular for some epithelial cancers of the female genital tract. Cloning and sequencing of amplified fragments confirmed the infection with HPV 18 and also revealed the presence of JC9813 DNA, another HPV with low oncogenic potential [23].

\section{Evidence of Soft Tissue Tumors in Skeletonized Individuals}

Alongside the neoplasias documented in human mummified remains, this review also includes the tumors of soft tissues that underwent calcification, which were observed in skeletal remains. Basically, this category includes the tumors affecting the female reproductive system, such as uterus myomas, generally leiomyomas, and other calcified concretions that can be found in archaeological contexts, such as ovary fibromas and teratomas.

The first detection of such a biological concretion was made in 1977 by Strouhal and Jungwirth [24], who observed a calcified mass in the pelvis of an adult female skeleton from Sayala (Nubia), dated between the 3rd and 4 th century AD. The calcification had large dimensions, $12.3 \mathrm{~cm}$ in diameter, with a mammillary aspect; X-ray evidenced no growing concentric layers, whereas histology showed the presence of collagen fibers without preferential orientation. The authors interpreted this mass as a calcified uterine leiomyoma.

The most ancient case of leiomyoma of the uterus was found in a group a skeletal remains in the burial ground of Corseaux-sur-Vevey, Switzerland, dating back to the Middle Neolithic Age (3200-2500 BC). A calcified spherical mass measuring $5.6 \times 5.2 \times 4.5 \mathrm{~cm}$ with irregular surface and spongy appearance of the interior structure was examined; the absence of a bony structure, the presence of organic matrix with collagen fibers and the apatite composition allowed to identify the calcified specimen as calcified leiomyoma [25].

Two other cases of leiomyomas come from the necropolis of Sion Sous-le-Scex, Valais, Switzerland, and are dat- 

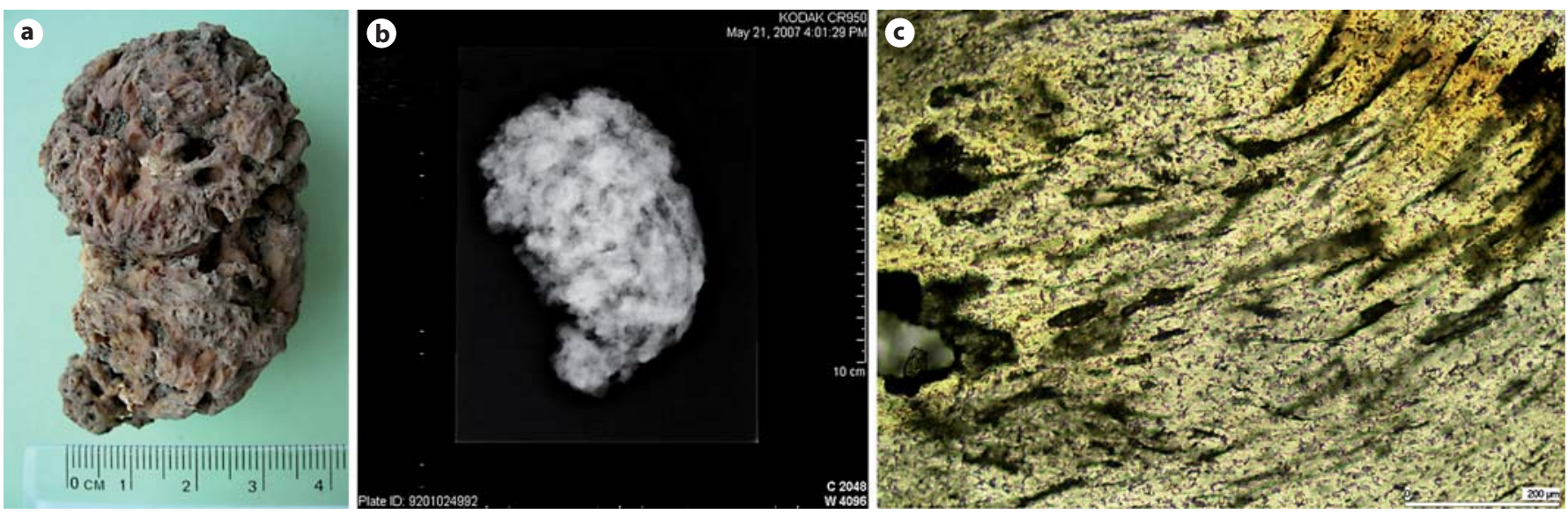

Fig. 10. Calcified leiomyoma associated to a 40- to 50-year-old female skeleton from Belgium (a); radiological (b) and histological aspects of the calcified mass (c; by courtesy of Prof. Kim Quintelier) [27].

ed between the 5th and 10th century AD, and from the necropolis of Rances, Vaud, dated between the 5th and 7 th century AD. The calcifications $(4.6 \times 3.2 \times 2.5$ and $3.0 \times 2.6 \times 1.8 \mathrm{~cm}$, respectively) were characterized by a whorl-like aspect in section [26].

From the post-medieval nunnery of the Poor Clares in Brussels (Belgium), active from the end of the 16th to the end of the 18th century, isolated calcified masses of 3 skeletons were observed in the pelvic cavities. The largest mass, $7.1 \times 4.7 \mathrm{~cm}$ in size and $85 \mathrm{~g}$ in weight, was associated with a 40/50-year-old woman (fig. 10a); another formation, measuring $5.3 \times 4.7 \mathrm{~cm}$ and weighing $45 \mathrm{~g}$, was associated with a female of $35 / 40$ years, and finally, the third calcification, $3.1 \times 2.5 \mathrm{~cm}$ and $8 \mathrm{~g}$ in weight, was observed in the pelvis of a 50/60-year-old woman. The calcified nodules were characterized by spherical or ovoid shape, irregular surface, spongy appearance and coarse trabecular texture. X-ray confirmed a calcified mass with scrolled and cloudy texture (fig. 10b), whereas histology showed no bone structure (fig. 10c). These features support the diagnosis of uterine leiomyomas [27].

A case of calcified mass is documented at a Muslim cemetery in Granada (Spain; 13th-15th century). A spheroid concretion with coral structure and sponge-like appearance $(6.1 \times 4.8 \mathrm{~cm}$ and $84 \mathrm{~g}$ in weight $)$ was found in the pelvic cavity of a mature woman. X-ray revealed a uniform density and no concentric layers; X-ray diffraction analysis demonstrated a basic composition of hydroxyapatite with carboapatite. Differential diagnosis evidenced a case of leiomyoma [28].
Among the skeletons excavated at Herculaneum (Italy), an ovoid calcified mass was associated with a 50/55-year-old female in the victims of the Plinian eruption of $79 \mathrm{AD}$. The concretion, $7.1 \times 6.3 \times 4.7 \mathrm{~cm}$, presented a mammillary surface and variegated radiological aspect, with no internal stratifications; micro-analytic examination demonstrated that the mass was mainly formed by hydroxyapatite. All these features are consistent with a calcified fibroleiomyoma of the uterus [29].

In the necropoles of Bazzano and Opi-Val Fondillo, Abruzzo (central Italy), two calcified masses in adult female skeletons from the 2 nd to 3 rd century $\mathrm{AD}$ and from the 6 th to 4 th century BC, respectively, were found. Using $\mathrm{X}$-ray, they appeared irregularly radio-opaque with large spaces, whereas chemical micro-analyses demonstrated the presence of calcium phosphate. Both cases were interpreted as uterine calcified fibromas [30].

From the necropolis of Alfedena in Abruzzo, dated to the 6th to 4th century BC, a spheroid mass $1.3 \mathrm{~cm}$ in diameter was associated with a female skeleton of $\sim 40$ years of age. Stereomicroscopic, radiological, histological and microchemical features are consistent with a diagnosis of well-mineralized intramural uterine fibroleiomyoma [31].

Another uterine myoma $\sim 7 \mathrm{~cm}$ in diameter is recorded in medieval Basel (Switzerland) [32].

Finally, a roundish structure containing 5 teeth was detected at the level of the thoracic spine in a skeleton from the Late Imperial necropolis of Rome. This irregular formation was $4 \mathrm{~cm}$ in diameter and $0.2-0.5 \mathrm{~cm}$ thick; the 5 teeth were remodeled, with altered surface and re-

Pathobiology 2012;79:257-267 
Table 1. Evidence of malignant soft tissue tumors in mummified remains

\begin{tabular}{llllll}
\hline No. & Tumor & Provenance & Dating & Age, years/sex & References \\
\hline 1 & Rectum adenocarcinoma & Egypt & Ptolemaic period & adult/M & $\begin{array}{l}\text { Zimmerman, 1995; } \\
\text { Zimmerman and Aufderheide, 2010 }\end{array}$ \\
\hline 2 & Rhabdomyosarcoma & Chile & $300-600$ AD & child/M & Gerszten and Allison, 1991 \\
\hline 3 & Colorectal adenocarcinoma & Italy & 15th century & $63 / \mathrm{M}$ & $\begin{array}{l}\text { Fornaciari, 1993; Fornaciari, 1994; } \\
\text { Marchetti et al., 1996; Ottini et al., } \\
\text { 2011 }\end{array}$ \\
\hline & & & & Fornaciari et al., 1989 \\
\hline
\end{tabular}

Table 2. Evidence of benign tumors in mummified remains

\begin{tabular}{|c|c|c|c|c|c|}
\hline No. & Tumor & $\begin{array}{l}\text { Prove- } \\
\text { nance }\end{array}$ & Dating & $\begin{array}{l}\text { Age, years/ } \\
\text { sex }\end{array}$ & References \\
\hline 1 & Ovarian cystadenoma & Egypt & Ptolemaic period & $50-55 / \mathrm{F}$ & Granville, 1825 \\
\hline 2 & Breast fibroadenoma & Egypt & $835 \mathrm{BC}$ & $35 / \mathrm{F}$ & Reyman and Peck, 1983 \\
\hline 3 & Skin squamous papilloma & Egypt & late dynastic period & adult?/F & Sandison, 1967 \\
\hline 4 & Skin histiocytoma & Egypt & $\mathrm{ND}$ & ND & Zimmerman, 1981 \\
\hline 5 & Bladder papilloma & Egypt & 1st- 3 rd century AD & adult/M & Zimmerman and Aufderheide, 2010 \\
\hline 6 & Verruca vulgaris & Egypt & ND & ND & Fulcheri, 1987 \\
\hline 7 & Lipoma & Chile & $1,100-1,200 \mathrm{AD}$ & $14 / \mathrm{M}$ & Gerszten and Allison, 1991 \\
\hline 8 & Angiokeratoma circumscriptum & Chile & 15th century AD & $9 / \mathrm{M}$ & $\begin{array}{l}\text { Horne and Kawasaki, 1984; Horne, } \\
1986\end{array}$ \\
\hline 9 & Verruca vulgaris & Chile & 15 th century AD & $9 / \mathrm{M}$ & Horne, 1986 \\
\hline 10 & Condyloma acuminatum & Italy & 16th century AD & $65 / \mathrm{F}$ & Fornaciari et al., 2003 \\
\hline 11 & Ovary cystoadenoma or teratoma & Italy & 19th century AD & $43-50 / \mathrm{F}$ & Ventura et al., 2006 \\
\hline
\end{tabular}

duced as shapeless roots. The ossified mass was identified as a mediastinal mature teratoma, until now the unique case documented in palaeopathology [33].

\section{Conclusions}

The cases of soft tissue neoplasias so far recorded in mummified remains are 15 . Among these cases, only 4 are identified as malignant tumors, as summarized in table 1. In particular, 1 case of rectal carcinoma from Egypt, 1 case of rhabdomyosarcoma from Chile, 1 case of colorectal carcinoma and 1 case of skin carcinoma from Italy were documented (table 1).

According to the classification based on the type of cell and tissue of origin, these tumors are mostly epithelial (carcinomas), whereas only 1 mesenchymal tumor, a rhabdomyosarcoma, originated from striated muscular tissue was found.
The other cases are benign tumors, including 2 adenomas, 1 adenoma or teratoma, 2 verrucae vulgaris, 1 lipoma, 2 papillomas, 1 histiocytoma, 1 angiokeratoma and 1 condyloma acuminatum; these findings were diagnosed in mummies from Egypt, Chile and Italy, as shown in table 2. Among the benign tumors, several are of epithelial origin, such as adenomas, verrucae, papillomas, angiokeratoma and condyloma acuminatum, whereas among the neoplasias of mesenchymal origin 1 originated from the connective tissue (histiocytoma) and 1 from the adipose tissue (lipoma).

The rarity of soft tissue tumors in palaeopathology, especially malignant ones, is a debated problem [34]. The main types of bone tumors known nowadays have been detected in ancient skeletal remains [35], but the absence of cancer of internal organs, such as lungs, liver, prostate, stomach or thyroid, which are frequent in modern populations, but have never been observed in hundreds of mummies examined around the world, is worth noting. 
Table 3. Evidence of calcified soft tissue tumors in skeletal remains

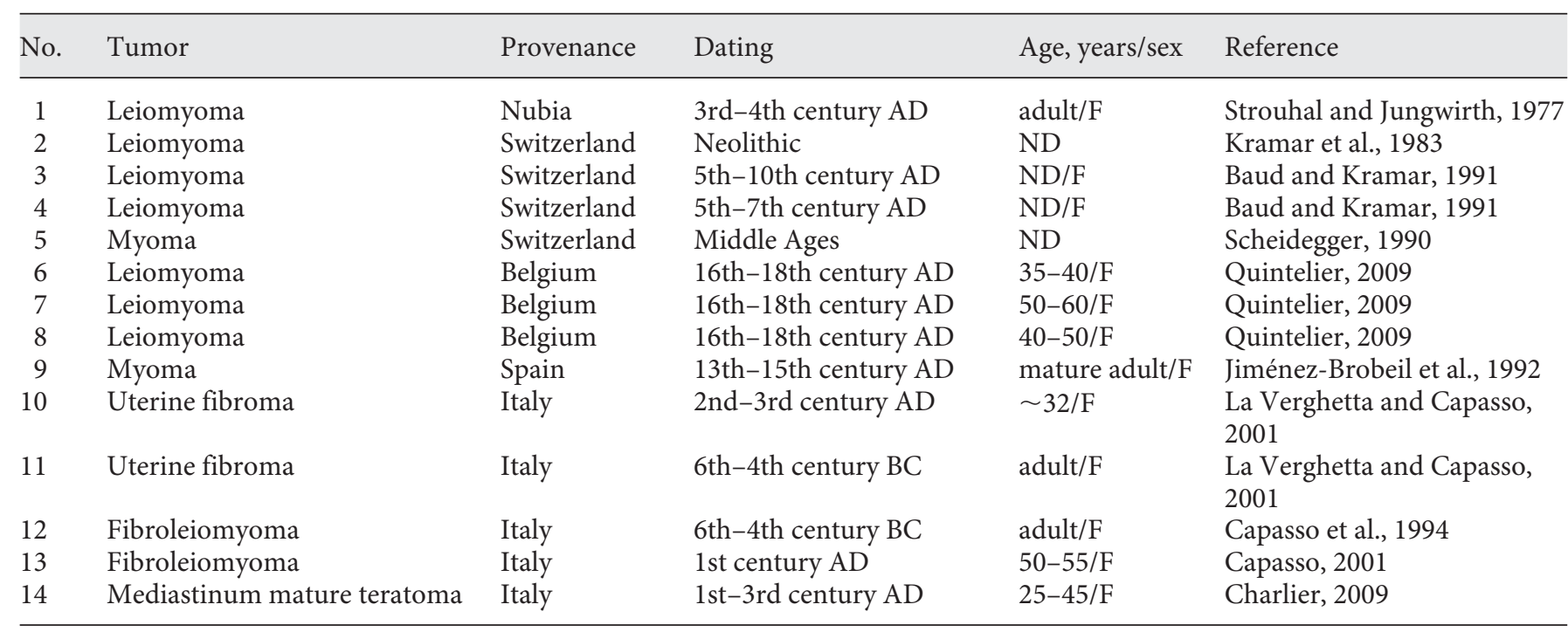

Concerning Egyptian mummies, the embalming practice of the dynastic period, which implied removal of the internal organs, prevented the opportunity to observe soft-tissue neoplastic phenomena. However, in other natural mummies, for example predynastic Egyptian, SouthAmerican and Aleutian mummies that conserved the internal organs, scarcity of reports needs to be explained otherwise.

It has been suggested that tumoral degeneration itself could lead to tissue alterations, making them fragile and more susceptible to rapid deterioration, but experimental studies performed to verify the effects of mummification on neoplastic tissue preservation have demonstrated that malignant tumors were histologically much better preserved than normal tissues. Therefore, the scarcity of reports on malignancies in mummies cannot be attributed to technical difficulties [36].

If we consider the malignancies which have a significant incidence in modern population, the lack of evidence in mummies could indicate a different occurrence in past societies. As already highlighted in the introduction, the life expectancy of modern populations explains the high incidence of cancer, which is the leading cause of death in developed countries and second leading cause of death in developing countries, as a result of population aging [37]; the average age at death in past societies was considerably lower, although variable in relation to geographic areas and chronological periods, and death arrived before cancer could manifest itself.
On the other hand, several risk factors related to the modern industrial society that have greatly raised the incidence of cancer in the present, such as cigarette smoke, pollution, chemical compounds, drugs and artificial radiations, were not present in the pre-Modern era, even if past populations were also exposed to natural carcinogenic factors.

It should also be considered that mummified remains are a much rarer finding than skeletal remains; furthermore, the hundreds of Egyptian mummies found during the 19th century were severely damaged by invasive examination methods, which aimed more at recovering artifacts or at satisfying curiosity around these ancient bodies than at investigating specific pathologies. On the other hand, the most recent studies on mummies have been carried out with non-invasive methods, but the diagnosis of soft tissue neoplasms is rather difficult using macroscopic external observation and radiological examination, for example; lesions suggestive of malignancies require confirmation by autopsy and histological examination, even if these investigation methods have been avoided in the last decades due to their destructive character.

However, a particular category of soft tissue neoplasias is well represented in the literature: tumors that underwent calcification and therefore could also be observed in association with skeletal remains. As summarized in table 3, 14 cases of calcified benign tumors are documented; we maintained the definitions used by authors, although 
tumors of the female reproductive system can be generally classified as leiomyomas. Therefore, 13 cases of leiomyomas, 1 from Nubia, 4 from Switzerland, 3 from Belgium, 1 from Spain, 4 from Italy and 1 case of teratoma from Italy, are documented.

In modern epidemiological studies, uterine leiomyomas show a significant incidence: this tumor was detected in $29.9 \%$ of 2,034 women studied, although only $3 \%$ of them had clinical symptoms. However, considering that uterine leiomyoma is four times more frequent in women over 40 years [38] and that this benign neoplasia calcifies in approximately $4 \%$ of cases [39], the relative rarity of palaeopathological findings can be well explained. Furthermore, the recovery of calcified soft tissues in archaeological remains is not always assured, as they can be easily mistaken for stones and it is only by accurate and meticulous excavation that these concretions can be detected.

In conclusion, it is important to pay maximum attention to any little sign of neoplastic lesion in ancient human remains in order to increase our limited knowledge about the type of tumors and relative incidence afflicting our ancestors. Comparison with modern data could help understand the evolution patterns of cancer in the history of mankind.

\section{Acknowledgment}

This work was supported by a grant from the Arpa Foundation (www.fondazionearpa.it).

\section{References}

1 Strouhal E: Malignant tumors in the Old 11 Ottini L, Falchetti M, Marinozzi S, AngeletWorld. Paleopathol Newsl 1994;85:1-6.

2 Capasso L: Antiquity of cancer. Int J Cancer 2005;113:2-13

3 Jemal A, Siegel R, Xu J, Ward E: Cancer statistics, 2010. CA Cancer J Clin 2010;60:277300.

4 Fornaciari G, Giuffra V: Les lésions tumorales osseuses; in Charlier P (ed): Ostéo-archéologie et techniques médico-légales: tendances et perspectives. Pour un 'Manuel pratique de paléopathologie humaine'. Paris, De Boccard, 2008, pp 393-412.

5 Zimmerman MRA: Paleohistology of ancient tissue tumors. Paper presented at the 22nd Annual Meeting of the Paleopathology Association held in Oakland, CA, on 28-29 March, 1995 (abstract). Paleopathol Newsl 1995;90(suppl):14-15.

6 Zimmerman MRA, Aufderheide C: Seven mummies of the Dakhleh oasis, Egypt: seventeen diagnoses. Paleopathol Newsl 2010; 150:16-23.

7 Gerszten E, Allison M: Human soft tissue tumors in Paleopathology; in Ortner DJ, Aufderheide AC (eds): Human Paleopathology: Current Syntheses and Future Options. Washington, Smithsonian Institute, 1991, pp 260-277.

8 Fornaciari G: Adenocarcinoma in the mummy of Ferrante I of Aragon, King of Naples (1431-1494). Paleopathol Newsl 1993;82:5-8.

$\checkmark$ Fornaciari G: Malignant tumor in the mummy of Ferrante Ist of Aragon, King of Naples (1431-1494). Med Secoli 1994;6:139-146.

10 Marchetti A, Pellegrini S, Bevilacqua G, Fornaciari G: K-RAS mutation in the tumour of Ferrante I of Aragon, King of Naples. Lancet 1996;347:1272. ti LR, Fornaciari G: Gene-environment interactions in the pre-Industrial Era: the cancer of King Ferrante I of Aragon (1431-1494). Hum Pathol 2011;42:332-339.

12 Fornaciari G, Bruno J, Corcione N, Tornaboni $\mathrm{D}$, Castagna M: Un cas de tumeur maligne primitive de la region naso-orbitaire dans une momie de la basilique de S. Domenico Maggiore à Naples (XVIe siècle); in Capasso L (ed): Advances in Paleopathology: Proceedings of the VII European Meeting of the Paleopathology Association: Lyon, September 1988. J Paleopathol Monogr Publ. Chieti, Solfanelli, 1989, pp 65-69.

13 Urteaga OB, Pack GT: On the antiquity of melanoma. Cancer 1966;19:607-610.

14 Granville AB: An essay on Egyptian mummies. Philos Trans R Soc Lond 1825;1:269316.

15 Aufderheide C, Rodriguez-Martin C: The Cambridge Encyclopedia of Human Paleopathology. Cambridge, Cambridge University Press, 1998.

16 Zimmerman MRA: A possible histiocytoma in an Egyptian mummy. Arch Dermatol 1981;117:364-365.

17 Sandison AT: Diseases of the skin; in Brothwell DR, Sandison AT (eds): Diseases in Antiquity. Springfield, Thomas, 1967, pp 449463.

18 Reyman TA, Peck WH: Egyptian mummification with evisceration per ano; in Cockburn A, Cockburn E, Reyman TA (eds): Mummies, Disease and Ancient Cultures. Cambridge, Cambridge University Press, 1983, pp 353-394.

19 Fulcheri E: Case no. 27: verruca vulgaris. Paleopathol Club Newsl 1987;31:2.
20 Horne PD, Kawasaki SQ: The prince of El Plomo: a paleopathological study. Bull NY Acad Med 1984;60:925-931.

21 Horne PD: Case no. 23: angiokeratoma circumscription. Paleopathol Club Newsl 1986; 27:1.

22 Ventura L, Miranda G, Mercurio C, Ciocca F, Fornaciari G: Paleopathology of the natural mummies of the inner Abruzzo region (XVIII-XIX century). Med Secoli 2006;18: 875-896.

23 Fornaciari G, Zavaglia K, Giusti L, Vultaggio C, Ciranni R: Human papillomavirus in a 16th century mummy. Lancet 2003;362:1160.

24 Strouhal E, Jungwirth J: Ein verkalktes Myoma uteri aus der späten Römerzeit in Ägyptisch-Nubien. Mitt Anthropol Ges 1977;107: 215-221.

25 Kramar C, Baud CA, Lagier R: Presumed calcified leiomyoma of the uterus. Morphologic and chemical studies of a calcified mass dating from the Neolithic period. Arch Pathol Lab Med 1983;107:91-93.

26 Baud CA, Kramar C: Soft tissue calcifications in pathology; in Ortner DJ, Aufderheide AC (eds): Human Paleopathology: Current Syntheses and Future Options. International Congress of Anthropological and Ethnological Sciences (12, Zagreb, 1988). Washington, Smithsonian Institute, 1991, pp 87-89.

27 Quintelier K: Calcified uterine leiomyomata from a post-medieval nunnery in Brussels, Belgium. Int J Osteoarchaeol 2009;19:436442

28 Jiménez-Brobeil SA, Botella Lopez MC, Ruiz Rodriguez L: A contribution to Medieval pathological gynaecology. J Paleopathol 1992;4:155-161. 
29 Capasso L: I fuggiaschi di Ercolano. Paleobiologia delle vittime dell'eruzione vesuviana del 79 d.C., Roma, L'ERMA di Bretschneider, 2001.

30 La Verghetta M, Capasso L: Paleopathology of uterine fibroma: direct and indirect sources (Italy); in La Verghetta M, Capasso L (eds): Proceedings of the XIII European Meeting of the Paleopathology Association (Chieti, Italy). Teramo, Edigraphital, 2001, pp 145148.

31 Capasso L, Baggieri G, Di Tota G, Meucci C: Probabile fibroleiomioma uterino calcificato dalla necropoli di Alfedena (L'Aquila), circa VI-IV secolo a.C. (Età del Ferro). Antropol Contemp 1994;17:13-18.
32 Scheidegger S: Ursachen und Verbreitung der Tumoren. Beiträge zur Paläopathologie. Tagungsberichte zum Paläopathologichen Symposium (Liestal, BL, 21-23 Juni 1984). Archäologie Museum 1990;18:38-41.

33 Charlier P, Huynh-Charlier I, Brun L, Devisme $\mathrm{L}$, Catalano $\mathrm{P}$ : Un tératoma mature médiastinal vieux de 1800 ans. Ann Pathol 2009;29:67-69.

34 David R, Zimmerman R: Cancer: an old disease, a new disease or something in between? Nat Rev Cancer 2010;10:728-733.

35 Thillaud PL: Paléopathologie du cancer: continuité ou rupture? Bull Cancer 2006;93: 767-773.

36 Zimmerman MRA: An experimental study of mummification pertinent to the antiquity of cancer. Cancer 1977;40:1358-1362.
Jemal A, Bray F, Center MM, Ferlay J, Ward E, Forman D: Global cancer statistics. CA Cancer J Clin 2011;61:69-90.

38 Selo-Ojeme D, Lawal O, Shah J, Mandal R, Pathak S, Selo-Ojeme U, Samuel D: The incidence of uterine leiomyoma and other pelvic ultrasonographic findings in 2,034 consecutive women in a north London hospital. J Obstet Gynaecol 2008;28:421-423.

39 Ueda H, Togashi K, Konishi I, Kataoka ML, Koyama T, Fujiwara T, Kobayashi H, Fujii S, Konishi J: Unusual appearances of uterine leiomyomas: MR imaging findings and their histopathologic backgrounds. Eur Radiol 2000;10:780-782. 